\title{
Biocontrol Activity of Aspergillus terreus ANU-301 against Two Distinct Plant Diseases, Tomato Fusarium Wilt and Potato Soft Rot
}

\author{
Hyong Woo Choi (iD)* and S. M. Ahsan \\ Department of Plant Medicals, College of Life Sciences and Biotechnology, Andong National University, Andong 36729 , \\ Korea \\ (Received on December 26, 2021; Revised on January 10, 2022; Accepted on January 11, 2022)
}

To screen antagonistic fungi against plant pathogens, dual culture assay (DCA) and culture filtrate assay (CFA) were performed with unknown soil-born fungi. Among the different fungi isolated and screened from the soil, fungal isolate ANU-301 successfully inhibited growth of different plant pathogenic fungi, Colletotrichum acutatum, Alternaria alternata, and Fusarium oxysporum, in DCA and CFA. Morphological characteristics and rDNA internal transcribed spacer sequence analysis identified ANU-301 as Aspergillus terreus. Inoculation of tomato plants with Fusarium oxysporum f. sp. lycopersici (FOL) induced severe wilting symptom; however, co-inoculation with ANU-301 significantly enhanced resistance of tomato plants against FOL. In addition, culture filtrate (CF) of ANU-301 not only showed bacterial growth inhibition activity against Dickeya chrysanthemi $(D c)$, but also demonstrated protective effect in potato tuber against soft rot disease. Gas chromatography-tandem mass spectrometry analysis of $\mathrm{CF}$ of ANU-301 identified 2,4-bis(1-methyl-1-phenylethyl)phenol (MPP) as the most abundant compound. MPP inhibited growth of $D c$, but not of $F O L$, in a dose-dependent manner, and protected potato tuber from the

*Corresponding author.

Phone) +82-54-820-5509, FAX) +82-54-820-5505

E-mail) hwchoi@anu.ac.kr

ORCID

Hyong Woo Choi

https://orcid.org/0000-0001-6049-4426

Handling Editor : Mee Kyung Sang

(c) This is an Open Access article distributed under the terms of the Creative Commons Attribution Non-Commercial License (http:// creativecommons.org/licenses/by-nc/4.0) which permits unrestricted noncommercial use, distribution, and reproduction in any medium, provided the original work is properly cited.

Articles can be freely viewed online at www.ppjonline.org. soft rot disease induced by $D c$. In conclusion, Aspergillus terreus ANU-301 could be used and further tested as a potential biological control agent.

Keywords : Aspergillus terreus, biological control agent, Dickeya chrysanthemi, Fusarium oxysporum f. sp. lycopersici, 2,4-bis(1-methyl-1-phenylethyl)-phenol

To ensure food security in the foreseeable coming decades, agricultural production must boost to keep pace with the expanding human population. There is currently a tremendous drive to create low-input and more sustainable agricultural strategies that include replacements to chemicals for pest and disease management. Thus, it is crucial to investigate the function of soil microorganisms which can stimulate growth and prohibit disease, as well as their use as biological control agent (Ab Rahman et al., 2018).

The Fusarium genus is one of the most sophisticated and versatile in the Eumycota, and the Fusarium oxysporum species group features plant, animal, and human diseases, as well as a varied diversity of non-pathogens (Gordon, 2017). Members of the Fusarium genus are a widespread soil-borne pathogen that infects a broad variety of horticultural and food crops, causing devastating vascular wilts, rots, and damping-off diseases (Bodah, 2017). F. oxysporum penetrates the root epidermis, spreads through the vascular tissue, and conquers the plant's xylem vessels, resulting in vessel blockage and severe water stress (Singh et al., 2017). The tomato (Lycopersicon esculentum) is a crop grown on a global scale and is eaten raw or processed in a variety of products (Brookie et al., 2018; Srinivas et al., 2019) and its production is largely hampered by Fusarium wilt caused by $F$. oxysporum f. sp. lycopersici (Borisade et al., 2017).

Dickeya chrisanthemi (Dc, formerly Erwinia chrysan- 
themi) is an enterobacteria that causes blackleg and soft rot diseases on a wide variety of agricultural and aesthetic plants, most notably banana, Chrysanthemum spp., Dianthus spp., maize, potato, and tomato (Ma et al., 2007; Toth et al., 2011). The signs of soft rot are mostly produced by secreted pectinases that breakdown pectin in the intermediate lamella and primary cell walls (Hugouvieux-Cotte-Pattat et al., 2014). $D c$ is a serious bacterial pathogen associated with potato soft rot disease (Cating et al., 2008; Pérombelon, 2002; Potrykus et al., 2016; Samson et al., 2005; Sławiak et al., 2009; Toth et al., 2011; Van der Wolf et al., 2014; Végh et al., 2014).

Rhizosphere-resident fungi that benefit plants are often referred to as 'Plant growth promoting fungi' (PGPF). They are also a major source of biotic inducers known to confer several benefits on their host plants, and hence play a critical role in sustainable agriculture (Murali et al., 2021). The well-known fungal genera Aspergillus, Fusarium, Penicillium, Piriformospora, Phoma, and Trichoderma are the most commonly reported PGPF when it comes to ensuring improved plant development and induced systematic resistance (Hossain et al., 2017). Current findings have shown that Aspergillus spp. isolated from soil increases the synthesis of indole-3-acetic acid (Abri et al., 2015; Kumar et al., 2017; Ozimek et al., 2018), phosphorus solubilization (Li et al., 2016), and zinc oxide solubilization (Šebesta et al., 2020). Siderophore formation (Ghosh et al., 2017; Mahmoud and Abd-Alla, 2001; Nenwani et al., 2010; Patel et al., 2017; Salas-Marina et al., 2011), starch hydrolysis (Tsukagoshi et al., 2001) and antimicrobial secondary metabolites production (Lenartowicz et al., 2015). Secondary metabolites are low molecular weight molecules generated by fungi that are not essential for growth or reproduction but impose a competitive advantage on the organism. For instance, they may limit the development of organisms with which they interact, so impairing often vital biochemical reactions (Mosunova et al., 2020). The genus Aspergillus is the most prevalent, yielding an abundance of beneficial bioactive antimicrobial secondary metabolites (El-hawary et al., 2020; Ortega et al., 2021).

Aspergillus terreus is a significant saprophytic filamentous fungus found in soil that performs a variety of growthpromoting roles and produces antimicrobial secondary metabolites such as phenols and flavanoids (Javed et al., 2020; Vassileva et al., 2020). Additionally, some studies indicate that it has antifungal (Abdallah et al., 2015; Al-Shibli et al., 2019; Joncy et al., 2019; Waqas et al., 2015) and antibacterial properties (Cazar et al., 2005; Liu et al., 2018; Zaman et al., 2020). Additional research is required to determine its potential not only as a growth promoter for plants, but also as a biocontrol agent against a number of vital plant diseases.

The objective of the present study is to isolate fungal strain with biocontrol activities from the soil. ANU-301 isolated from the screening was identified as $A$. terreus by morphological and molecular analysis. Importantly, ANU301 significantly suppressed tomato Fusarium wilt and potato soft rot. To our knowledge, it is the first report of biological control activity of $A$. terreus against $F$. oxysporum and $D c$.

\section{Materials and Methods}

Plant pathogens. Fungal (Colletotrichum acutatum, Alternaria alternata, and $F$. oxysporum) and bacterial $(D c)$ plant pathogens were used in this study. $F$. oxysporum f. sp. $l y$ copersici strain KACC 40038 (FOL) was generously provided by Korean Agricultural Culture Collection (KACC), Korea. Fungal and bacterial strains were grown at potato dextrose agar (PDA) and nutrient agar (NA) media, respectively.

For tomato Fusarium wilt assay, FOL was grown at PDA for 10 days at $28^{\circ} \mathrm{C}$. Surface of fungal mycelia on PDA medium was filled with $5 \mathrm{ml}$ of sterile distilled water (SDW), fungal spores were collected using a spreader, and filtered through cheesecloth. The spore concentration was adjusted to $1 \times 10^{6}$ conidia/ml by using a hemocytometer (Paul Marienfeld Superior, Lauda-Königshofen, Germany).

For potato soft rot assay, $D c$ was grown at nutrient broth (MBcell, Kisanbio, Seoul, Korea) medium for 2 days at $28^{\circ} \mathrm{C}$. Bacterial cells were collected by centrifugation at $13,000 \mathrm{rpm}$ and suspended in sterile tap water $\left(10^{8} \mathrm{cfu} / \mathrm{ml}\right)$ $\left(\mathrm{OD}_{600}\right.$ of $\left.1.0=10^{9} \mathrm{cfu} / \mathrm{ml}\right)$.

Isolation and screening of the antagonistic activity of ANU-301. Soils were sampled from Agisan in Andong, South Korea. One gram of soil samples was suspended with $10 \mathrm{ml} \mathrm{SDW}$, vortexed for $10 \mathrm{~min}$ and sieved with cheesecloth to remove large soil particle. Supernatant was serially diluted and spread on PDA medium containing 50 $\mu \mathrm{g} / \mathrm{ml}$ streptomycin. Different fungal colonies were recovered and grown at PDA media.

Fungal isolates were screened for their antagonistic activity against different plant pathogenic fungi by using dual culture and culture filtrate assays (DCA and CFA, respectively). DCA and CFA were performed as previously described with minor modifications (Park et al., 2021; Shin et al., 2019). The pathogen and soil-isolated fungi were grown at PDA media, and agar-mycelium discs $(6 \mathrm{~mm}$ diameter) were taken from the edge of an actively grow- 
ing fungal colony for DCA. Each agar-mycelium disc was placed on PDA with $40 \mathrm{~mm}$ distance and incubated at $25^{\circ} \mathrm{C}$ for 7 days. One of the soil-isolated fungi named Andong National University-301 (ANU-301) showed significant inhibition activity against different fungal pathogens.

To prepare the culture filtrate (CF), ANU-301 was cultured in potato dextrose broth (PDB) at $25^{\circ} \mathrm{C}$ for 5 days, centrifuged at 13,000 rpm for $10 \mathrm{~min}$, and supernatant was filtered with with $0.22 \mu \mathrm{m}$ filters. For CFA, agar-mycelium discs of pathogens were placed in the middle of PDA media with or without $10 \% \mathrm{CF}$, then measured diameter of fugal mycelium after growing at $25^{\circ} \mathrm{C}$ for 5 days. To prepare the PDA with $10 \% \mathrm{CF}$, filter sterilized $\mathrm{CF}$ was added to autoclaved PDA after cooling to about $60^{\circ} \mathrm{C}$.

For DCA and CFA, three replicates were prepared for each experiment, and plates inoculated only with the pathogen were used as control. The antagonistic activity of ANU-301 or its CF was expressed as the percentage of pathogen mycelium growth inhibition compared to the control.

Identification of ANU-301. For microscopic observation of conidiophore and conidia, ANU-301 was grown at PDA medium and observed by using the microscope (BX50, Olympus, Tokyo, Japan). The obtained image was analyzed by using Image J software. For molecular identification, the rDNA genes containing highly conserved internal transcribed spacer (ITS) regions were amplified by polymerase chain reaction (PCR) and sequenced. Genomic DNA (gDNA) was extracted from mycelia of ANU-301 using HiGene Genomic DNA Prep Kit (BIOFACT, Daejeon, Korea) according to the manufacturer's instructions. The PCR amplification and sequencing of the ITS rDNA was performed using the following primer set: ITS1: 5'-TCCGTAGGTGAACCTGCGG-3' and ITS4: 5'-TCCTCCGCTTATTGATATGC-3' (White et al., 1990). PCR was performed in a $30 \mu \mathrm{l}$ reaction mixture containing $15 \mu \mathrm{l}$ of $2 \times$ Taq PCR Pre-Mix (Solgent, Daejeon, Korea), $1 \mu \mathrm{lof} 10 \mathrm{pmol} / \mu \mathrm{l}$ of ITS 1 and ITS4 primers, and $1 \mu \mathrm{g}$ of gDNA. PCR amplification was carried out using thermal cycler (Multigene Gradient, Labnet, Edison, NJ, USA) by following amplification conditions: denatured at $95^{\circ} \mathrm{C}$ for 5 min, 33 cycles of $94^{\circ} \mathrm{C}$ for $30 \mathrm{~s}, 56^{\circ} \mathrm{C}$ for $10 \mathrm{~s}, 72^{\circ} \mathrm{C}$ for $40 \mathrm{~s}$, and final extension at $72^{\circ} \mathrm{C}$ for $10 \mathrm{~min}$. PCR products were analyzed by gel electrophoresis and purified using PCR purification Kit (BIOFACT) according to the manufacturer's instructions for sequencing. The resulting sequence of the ITS rDNA of ANU-301 was analyzed with NCBI's GenBank sequence database (http://www.ncbi.nlm,nih.gov) to identify the closest species relatives and phylogenetic tree was constructed by MEGA-X software using maximum likelihood method (Kumar et al., 2018). The resulting sequence of the complete ITS rDNA of ANU-301 has been deposited in the NCBI (accession no. OL831165).

Biocontrol activity of ANU-301 in tomato and potato. Tomato (Solanum lycoperiscum L. cv. Seogwang) plants were grown in plastic tray $(55 \times 35 \times 15 \mathrm{~cm})$ containing soil mix (peat moss, perlite, and vermiculite; $5: 3: 2, \mathrm{v} / \mathrm{v} / \mathrm{v}$ ) at $28^{\circ} \mathrm{C}$ with a day length of $16 \mathrm{~h}$ at a light intensity of 70 $\mu \mathrm{mol}$ photons $/ \mathrm{m}^{2} / \mathrm{s}$. Six seedlings at the two-leaf stage were transplanted to a plastic pot $(5 \times 15 \times 10 \mathrm{~cm})$ containing the same soil mix. Two-week-old tomato plants were used for pathogen inoculation experiment. For biological control assay, tomato plants were uprooted and submerged into 1 $\times 10^{6}$ conidia/ml of $F O L$ in the absence or presence of $1 \times$ $10^{8}$ conidia/ml of ANU-301 and planted back. The infected plants were incubated in a controlled chamber at $28^{\circ} \mathrm{C}$ with $100 \%$ relative humidity for 2 weeks.

Potato (Solanum tuberosum L. cv. Sumi) tubers were surface sterilized by immersing sequentially in $1 \% \mathrm{NaOCl}$ (5 $\mathrm{min}), 70 \%$ ethanol (5 min) and washed 3 times with SDW. To prepare the inoculum, $2 \times 10^{6} \mathrm{cfu} / \mathrm{ml}$ of $D c$ was mixed with or with our 1:50 diluted CF of ANU-301 in 1:1 ratio (Final concentrations were $10^{6} \mathrm{cfu} / \mathrm{ml} D c$ and $1 / 100$ diluted CF of ANU-301). For pathogenicity assay, $10 \mu \mathrm{l}$ of each mixture was directly injected into potato tubers by using the pipette. The inoculated potato tubers were placed in plastic container and incubated at $25^{\circ} \mathrm{C}$ with $100 \%$ relative humidity. The diseased area in all cases was calculated from area of the macerated region by using the ImageJ program to calculate percent disease severity. Three independent trials were carried out with three replicates. For control experiments, potato tubers were injected with $10 \mu \mathrm{l}$ of sterilized distilled water.

Gas chromatography-tandem mass spectrometry analysis. ANU-301 was inoculation in 11 of PDB medium for 5 days. After cultivation, broth medium was centrifuged at $10,000 \times \mathrm{g}$ for $10 \mathrm{~min}$ and supernatant transferred to the conical flasks. In each conical flask, ethyl acetate were added to supernatant in a 1:1 ratio, shaken, and kept for overnight. Then, extraction solution were dried using a rotary evaporator. Extracts were dissolved in methanol for gas chromatography-tandem mass spectrometry (GC-MS/ MS) analysis and in DMSO for antifungal test. For GCMS/MS analysis, 5977A Series GC/MSD System (Agilent Technologies, Santa Clara, CA, USA) was used. Temperature program of $40^{\circ} \mathrm{C}$ (1 min hold) to $300^{\circ} \mathrm{C}(10 \mathrm{~min}$ hold) at a rate of $10^{\circ} \mathrm{C} / \mathrm{min}$. The injector and mass interface 
temperature was $300^{\circ} \mathrm{C}$, and the gas flow rate of the carrier gas, helium, was $1.0 \mathrm{ml} / \mathrm{min}$. Injection mode was split and mass range was 50 to $400(\mathrm{~m} / \mathrm{z})$. The result was analyzed using the National Institute of Standards and Technology spectral library version 11 (NIST 11 spectral library).

MPP against pathogens. MPP (2,4-bis(1-methyl1-phenylethyl)-phenol) was purchased from Tokyo Chemical Industry (TCI; Cat. No. B2772). MPP was dissolved in DMSO to prepare $100 \times$ stock solutions, and then mixed with pathogen containing media to the final concentrations.

\section{Results}

Screening of fungi with antifungal activity. To screen the soil fungi with biocontrol activity against different plant pathogens, unknown fungal isolates were recovered from the soil by plating on PDA media, then screened by DCA and CFA (Fig. 1). One of the fungal isolate, ANU-301, showed distinct growth inhibition activity (GIA) against different plant pathogenic fungi, such as $C$. acutatum, $A$. alternata, and $F$. oxysporum, in DCA and CFA (Fig. 1A). In DCA, GIA of ANU-301 against $F$. oxysporum was about $58.5 \%$, then followed by C. acutatum (40.1\%) and A. alternata (27.3\%) (Fig. 1B). By contrast, ANU-301 showed the highest GIA against $C$. acutatum (62.5\%), whereas much lower GIA against $A$. alternata $(21.7 \%)$ and $F$. oxysporum (20.2\%), in CFA. Although ANU-301 showed different levels of antifungal activity against different plant pathogens, it seems likely have broad spectrum control efficiency against different fungal pathogens.

Identification of ANU-301. To identify the ANU-301, morphological characteristics under the microscope and ITS sequencing-based phylogenetic analysis was performed (Fig. 2). ANU-301 incubated in PDA grew well and produced white-colored mycelial mat (Fig. 2A and B). Under the microscope, mycelia have a septum and asexual

\begin{tabular}{|c|c|c|c|c|c|c|}
\hline Pathogen & \multicolumn{2}{|c|}{ C. acutatum } & \multicolumn{2}{|c|}{ A. alternata } & \multicolumn{2}{|c|}{ F. oxysporum } \\
\hline ANU-301 & - & + & - & + & - & + \\
\hline $\begin{array}{l}\text { Dual } \\
\text { culture } \\
\text { assay } \\
\text { (DCA) }\end{array}$ & & & & & & \\
\hline $\begin{array}{l}\text { Culture } \\
\text { filtrate } \\
\text { assay } \\
\text { (CFA) }\end{array}$ & & & & & & \\
\hline
\end{tabular}

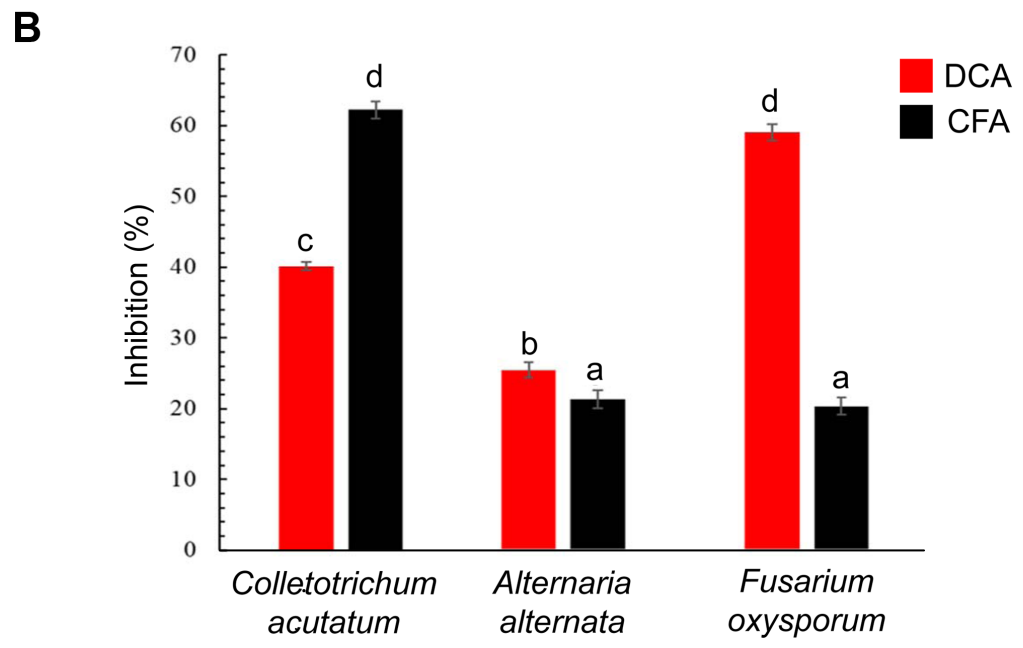

Fig. 1. Antifungal activity of ANU-3001. (A) Representative picture of DCA and CFA. (B) Growth inhibition percentage based on DCA and CFA. 

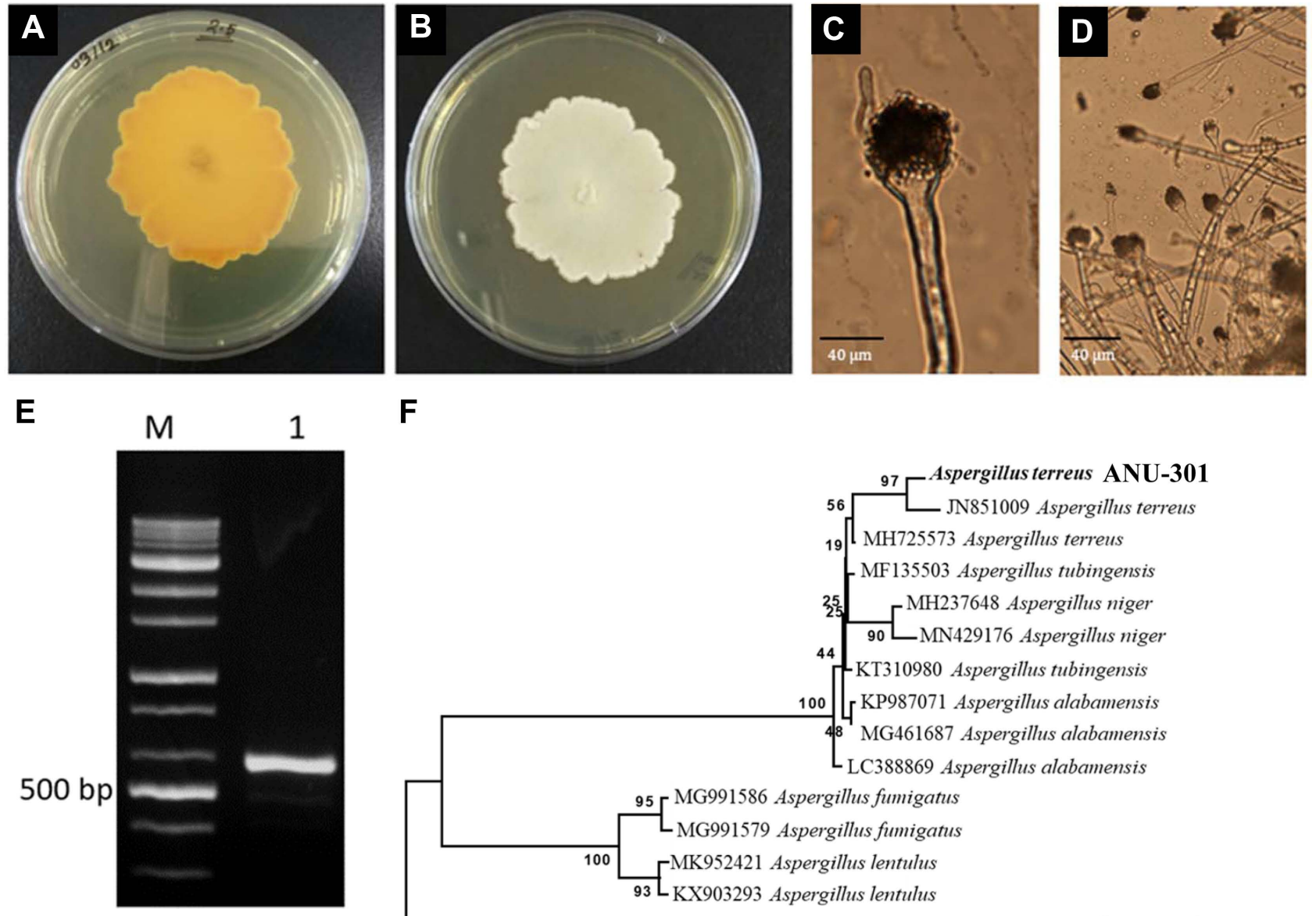

$\mathbf{F}$

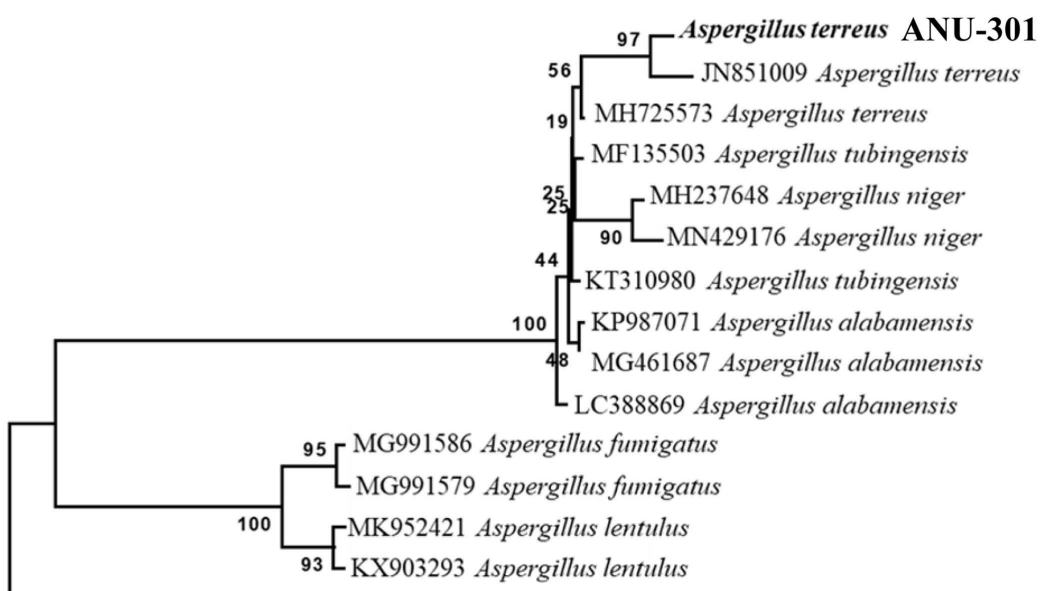

MH856382 Penicillium spinulosum

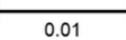

Fig. 2. Morphological and molecular identification of ANU-301 as Aspergillus terreus. (A-D) Photograph of colonial and conidiophore morphology on potato dextrose agar (PDA) medium. (A, B) ANU-301 showed white-colored mycelial growth on PDA medium. (A) Lower side. (B) Upper side. (C, D) Microscopic observation of conidiophore. Scale bars $=40 \mu \mathrm{m}$. (E) Internal transcribed spacer (ITS) amplification; M, marker 1 kb; 1, band of ITS (578 bp). (F) Phylogenetic tree based on ITS sequence of Aspergillus terreus ANU-301 (bold), its closely related Aspergillus species, and distantly related Penicillium spinulosum as outgroup.

conidia were observed arising from globose-shaped conidiophores, which is a characteristic of Aspergillus spp. (Fig. $2 \mathrm{C}$ and D). To further identify the ANU-301, ITS region was amplified by PCR and sequenced for phylogenetic analysis (Fig. 2E and F). From the analysis, ANU-301 showed the highest sequence homology with $A$. terreus and formed distinct clade from the other Aspergillus spp. Based on these procedures, it is named as $A$. terreus isolate ANU301 (ANU-301 from now on).

Biocontrol activity of ANU-301 against tomato Fusarium wilt disease. As ANU-301 showed the highest GIA against FOL in DCA, its biocontrol activity against tomato Fusarium wilt disease was examined (Fig. 3). Two-weekold tomato plants were inoculated by submerging the roots in $10^{6}$ conidia/ml of $F O L$ with or without $10^{8}$ conidia $/ \mathrm{ml}$ of ANU-301. Mock or ANU-301 treated plants showed no significant differences in growth rate; however, tomoto plants showed very severe growth retardation and wilting phenotype at 2 weeks after inoculation with FOL (Fig. 3A and B). Importantly, tomato plants co-inoculated with $F O L$ and ANU-301 showed significantly reduced disease symptoms.

To confirm whether ANU-301 has direct effect, mycelial growth of FOL in the absence or presence of ANU-301 was observed microscopically (Fig. 3C). Abnormal large vesicle formation was observed inside the hyphae of $F O L$ at the contact point with ANU-301, and purple-colored pigmentation of FOL mycelium was observed during the DCA. These findings suggest that ANU-301 somehow 

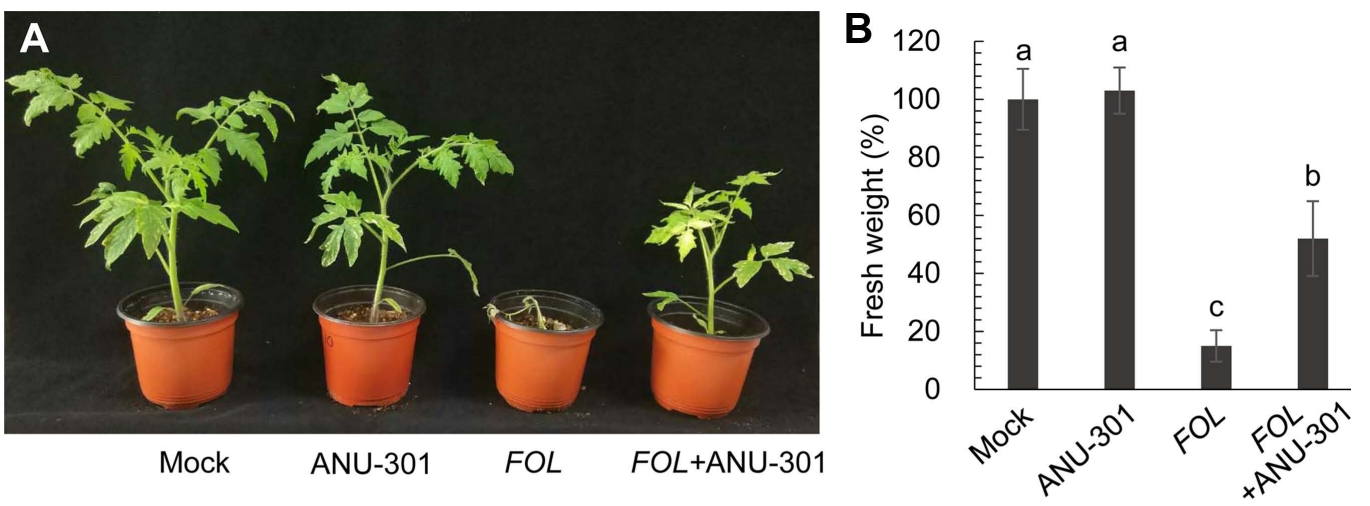

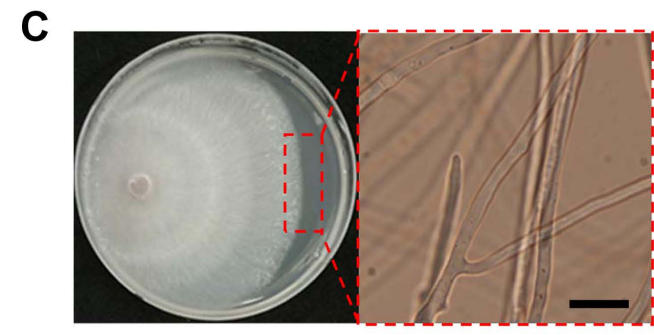

FOL

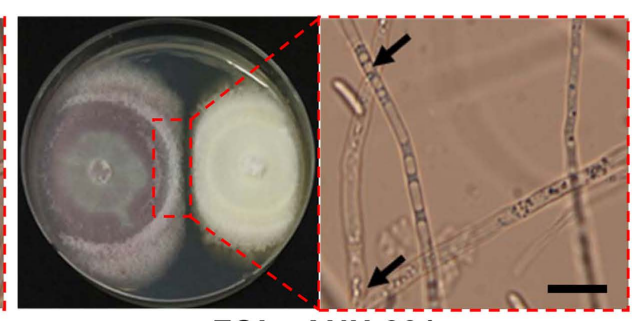

FOL+ ANU-301

Fig. 3. Biocontrol activity of ANU-301 against tomato Fusarium wilt disease. (A) Representative picture of disease symptom developed on tomato plants inoculated with F. oxysporum f. sp. lycopersici $(F O L)$ with or without ANU-301. (B) Fresh weight of tomato plants 7 dpi with FOL in the absence or presence of ANU-301. (C) Microscopic observation of mycelia of FOL during the dual culture assay with ANU-301. To show mycelial growth of FOL during DCA against ANU-301, part of Fig. 1A was enlarged. Scale bars $=20 \mu \mathrm{m}$.

A

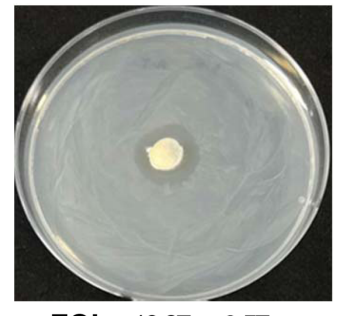

ZOI: $19.67 \pm 0.57 \mathrm{~mm}$

B

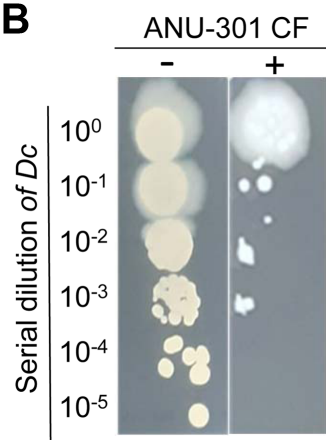

C

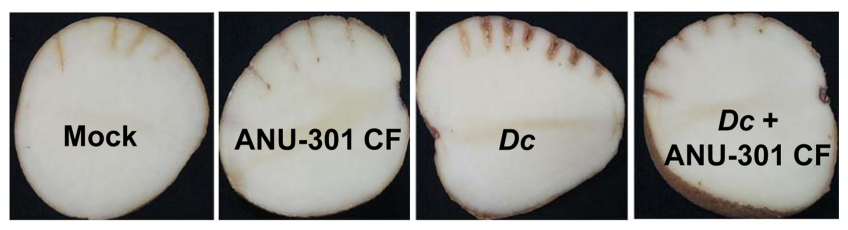

D

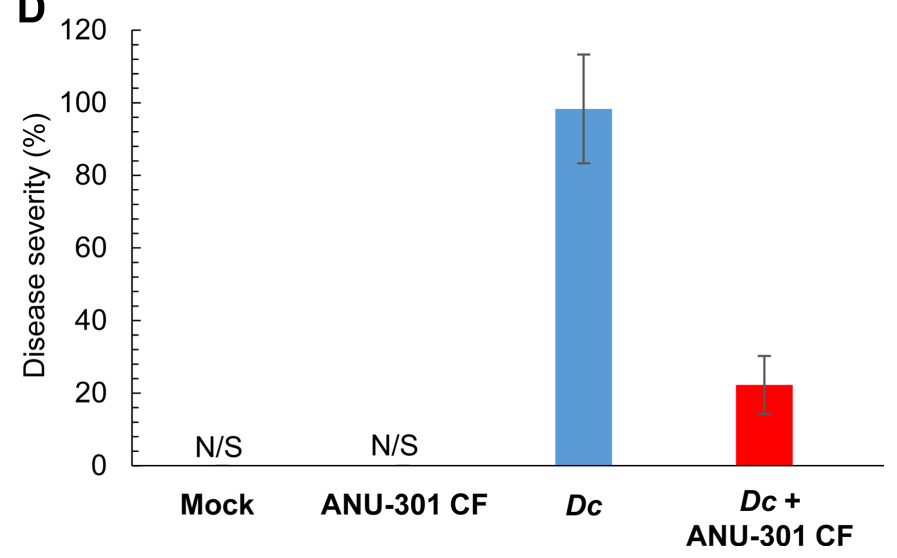

Fig. 4. Biocontrol activity of ANU-301 against potato soft rot disease. (A) Antibacterial activity of ANU-301 against Dickeya chrysanthemi $(D c)$ by agar plug diffusion assay. Diameter of zone of inhibition (ZOI) is shown below. (B) Growth inhibition of $D c$ by ANU-301 culture filtrate (CF). Plus (+) and minus (-) symbols mean presence and absence of $10 \%$ CF of ANU-301, respectively. (C, D) Biocontrol activity of CF of ANU-301 against potato soft rot disease caused by Dc. Representative disease symptoms (C) and severity (D) of potato tuber 2 weeks after inoculation with $D c$ in the presence or absence of CF of ANU-301. N/S, no symptom. 
alters physiology of $F O L$, thereby reducing their growth. Taken together, ANU-301 not only showed antifungal activity against $F O L$ in vitro, but also successfully suppressed tomato Fusarium wilt disease in pot experiments.

Biocontrol activity of ANU-301 against potato soft rot disease. To further examine whether ANU-301 has antibacterial activity, agar plug diffusion assay was performed against $D c$, a causal agent of potato soft rot disease. Interestingly, ANU-301 also showed antibacterial activity as developed clear zone in $D$ c grown NA media (Fig. 4A). Diameter of zone of inhibition (ZOI) was $19.67 \pm 0.57$ $\mathrm{mm}$. Antibacterial activity of CF of ANU-301 was examined. In this assay, 1:100 diluted CF of ANU-301 was mixed with $10^{6} \mathrm{cfu} / \mathrm{ml}$ of $D \mathrm{c}$, incubated for $1 \mathrm{~h}$, then serially diluted and plated on NA media. As shown in Fig. 4B, CF of ANU-301 successfully suppressed the growth of $D c$, suggesting ANU-301 also has antibacterial activity against Dc.

As CF of ANU-301 showed antibacterial activity against $D c$, its biological control activity against potato soft rot disease was also analyzed. As expected co-treatment of CF of ANU-301 significantly reduced disease symptom developed by $D c$ in potato tuber (Fig. $4 \mathrm{C}$ and D). In mock- and
ANU-301 CF-treatd potato, none of visible symptoms were observed, whereas $D c$-inoculated potato developed soft rot symptoms. Co-treatment with ANU-301 CF significantly reduced the diseased severity in potato by $79.1 \%$ (Fig. 4D). Taken together, ANU-301 showed biological control activity against two distinct plant pathogens, $F O L$ and $D c$.

Identification of MPP as a major antibacterial secondary metabolite in the CF of ANU-301. To further examine the major antimicrobial secondary metabolites in CF of ANU-301, GC-MS/MS experiment was performed. From the different compounds identified, MPP was the most abundant from the CF of ANU-301 (abundance: 15.05\%), and followed by 2,3,4,5-tetraphenyl-1H-pyrrole (abundance: 14.01\%), 2,6-bis(1,1-dimethylethyl)-4-(1-methyl1-phenylethyl)-phenole, octadecane and tatracosane (Table 1, Fig. 5).

MPP successfully suppressed bacterial growth of $D c$, in NA media as developed clear zone in filter disk diffusion assay $(10 \mu \mathrm{l}$ of $400 \mathrm{ppm}$ MPP or 1/100 diluted CF were used) (Fig. 6A), but not of FOL (Supplementary Fig. 1). MPP-induced diameter of ZOI was $14.04 \pm 0.09 \mathrm{~mm}$. Bacterial growth was measured by using the spectrophotometer at $\mathrm{OD}_{600}$ in the presence of different concentrations of MPP

Table 1. List of 20 most abundant chemical compounds identified from CF of ANU-301 by GC-MS/MS analysis

\begin{tabular}{|c|c|c|c|c|}
\hline No. & Compounds & R.T. (min) & $\begin{array}{l}\text { Chemical } \\
\text { formula }\end{array}$ & $\begin{array}{c}\text { Abundance } \\
(\%)\end{array}$ \\
\hline 1 & 2,4-bis(1-methyl-1-phenylethyl)-phenol & 11.94 & $\mathrm{C}_{24} \mathrm{H}_{26} \mathrm{O}$ & 15.05 \\
\hline 2 & 2,3,4,5-tetraphenyl-1H-pyrrole & 12.092 & $\mathrm{C}_{28} \mathrm{H}_{21} \mathrm{~N}$ & 14.01 \\
\hline 3 & 2,6-bis(1,1-dimethylethyl)-4-(1-methyl-1-phenylethyl)-phenol & 9.383 & $\mathrm{C}_{23} \mathrm{H}_{32} \mathrm{O}$ & 7.18 \\
\hline 4 & Octadecane & 12.6 & $\mathrm{C}_{18} \mathrm{H}_{38}$ & 4.83 \\
\hline 5 & Tetracosane & 11.156 & $\mathrm{C}_{24} \mathrm{H}_{50}$ & 4.21 \\
\hline 6 & Phenol, 2-(1,1-dimethylethyl)-4-(1-methyl-1-phenylethyl)- & 9.144 & $\mathrm{C}_{19} \mathrm{H}_{24} \mathrm{O}$ & 3.8 \\
\hline 7 & Methyl stearate & 9.585 & $\mathrm{C}_{19} \mathrm{H}_{38} \mathrm{O}_{2}$ & 3.74 \\
\hline 8 & Tricosane & 10.536 & $\mathrm{C}_{23} \mathrm{H}_{48}$ & 3.63 \\
\hline 9 & Docosane & 9.974 & $\mathrm{C}_{22} \mathrm{H}_{46}$ & 3.44 \\
\hline 10 & Hexadecanoic acid, methyl ester & 8.598 & $\mathrm{C}_{18} \mathrm{H}_{36} \mathrm{O}_{2}$ & 2.7 \\
\hline 11 & Eicosane & 14.091 & $\mathrm{C}_{20} \mathrm{H}_{42}$ & 2.66 \\
\hline 12 & Octadecane, 1-iodo- & 14.693 & $\mathrm{C}_{18} \mathrm{H}_{37} \mathrm{I}$ & 1.77 \\
\hline 13 & Heneicosane & 9.456 & $\mathrm{C}_{21} \mathrm{H}_{44}$ & 1.51 \\
\hline 14 & 3H-Pyrrolo[3,2-f]quinoline, 1,2,3,5,7,9-hexamethyl- & 9.878 & $\mathrm{C}_{17} \mathrm{H}_{20} \mathrm{~N}_{2}$ & 1.46 \\
\hline 15 & Benzenepropanoic acid, 3,5-bis(1,1-dimethylethyl)-4-hydroxy-, methyl ester & 8.695 & $\mathrm{C}_{18} \mathrm{H}_{28} \mathrm{O}_{3}$ & 1.24 \\
\hline 16 & 10,18-Bisnorabieta-8,11,13-triene & 9.261 & $\mathrm{C}_{18} \mathrm{H}_{26}$ & 1.17 \\
\hline 17 & 1-Methyl-10,18-bisnorabieta-8,11,13-triene & 8.968 & $\mathrm{C}_{19} \mathrm{H}_{28}$ & 1.1 \\
\hline 18 & Pyridine-3-carbonitrile, 2-amino-4-(4-methoxyphenyl)-5-methyl-6-propyl- & 9.482 & $\mathrm{C}_{17} \mathrm{H}_{19} \mathrm{~N}_{3} \mathrm{O}$ & 0.93 \\
\hline 19 & Phenol, 2,4-bis(1,1dimethylethyl)- & 6.323 & $\mathrm{C}_{17} \mathrm{H}_{30} \mathrm{OSi}$ & 0.688 \\
\hline 20 & 2,4-Diphenyl-4-methyl-2(E)-pentene & 8.193 & $\mathrm{C}_{18} \mathrm{H}_{20}$ & 0.46 \\
\hline
\end{tabular}

$\mathrm{CF}$, culture filtrate; GC-MS/MS, gas chromatography-tandem mass spectrometry; R.T., retention time. 


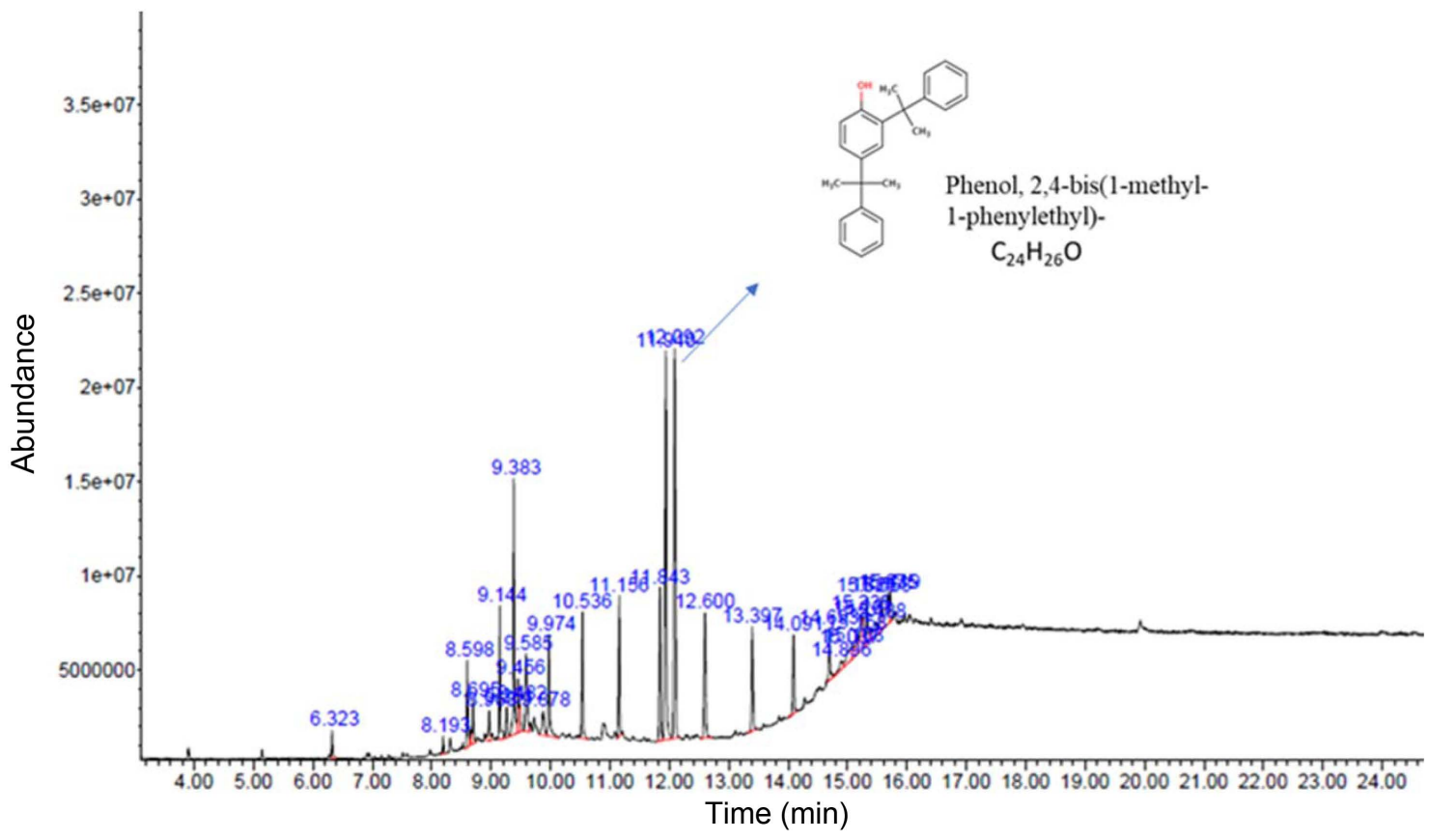

Fig. 5. Gas chromatography-tandem mass spectrometry chromatogram of culture filtrate of ANU-301. Chemical structure of the most abundant chemical compound 2,4-bis(1-methyl-1-phenylethyl)-phenol was shown above the peak (see Table 1 for the list of 20 most abundant chemical compound identified).

A

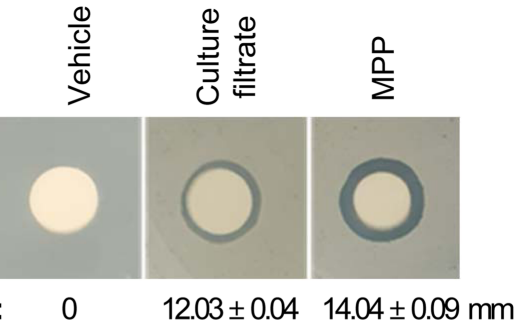

B

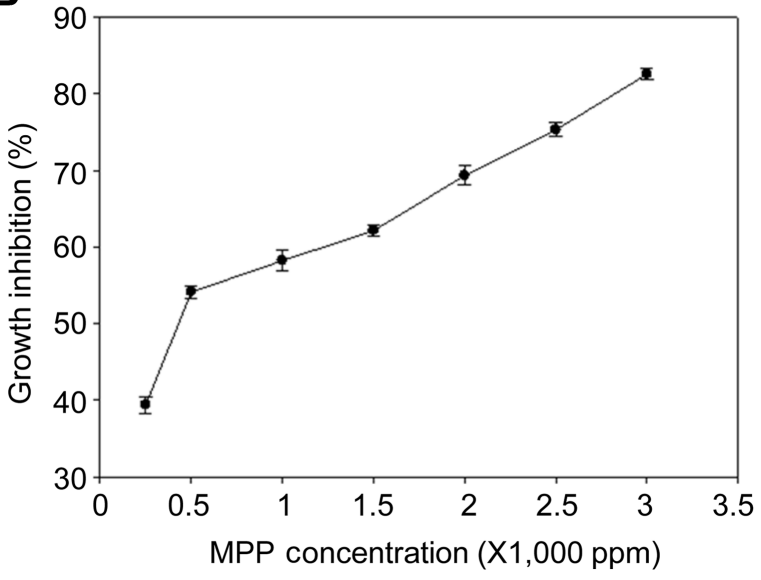

C

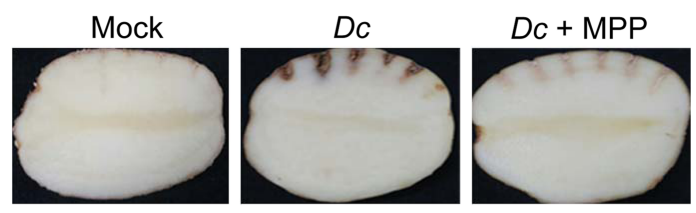

D

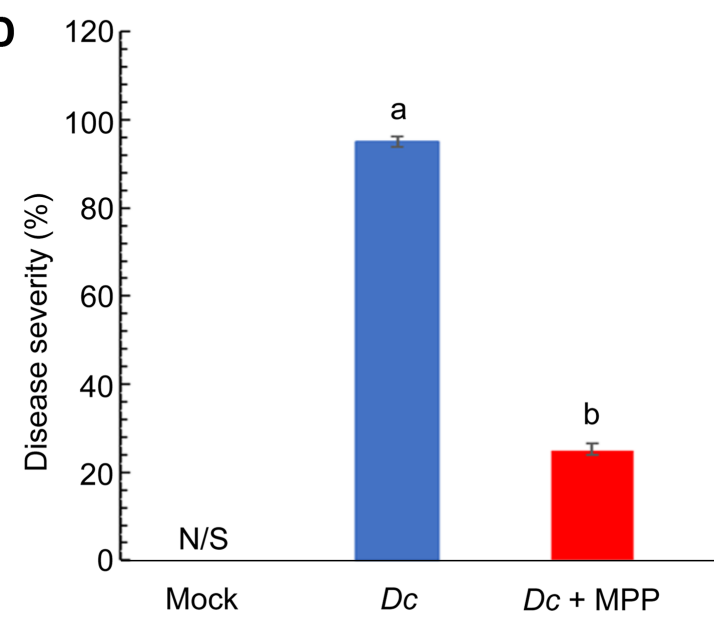

Fig. 6. Biocontrol activity of 2,4-bis(1-methyl-1-phenylethyl)-phenol (MPP) against Dickeya chrysanthemi (Dc). (A) Antibacterial activity of culture filtrate and MPP (400 ppm) against $D c$ by disc diffusion assay. Diameter of zone of inhibition (ZOI) is shown below. (B) Concentration-dependent growth inhibition of MPP on $D c$ growth in nutrient broth (NB) media. Cell growth was measured by spectrophotometer at $\mathrm{OD}_{600}$. Calculated $\mathrm{IC}_{50}$ was $505.9 \mathrm{ppm}$. (C, D) Biocontrol activity of MPP against potato soft rot disease caused by $D c$. Representative disease symptoms (C) and severity (D) of potato tuber 2 weeks after inoculation with $D c$ in the presence or absence of MPP. N/S, no symptom. 
(Fig. 6B). MPP inhibited growth of $D c$ in a concentrationdependent manner with a calculated $\mathrm{IC}_{50}$ of $505.9 \mathrm{ppm}$ $(\sim 1.5 \mathrm{mM})$. Biocontrol activity of MPP against potato soft rot disease was examined. As expected, co-inoculation of $D c$ with MPP significantly reduced disease severity in potato tuber (Fig. 6C and D). Mock-inoculated potato developed negligible browning at the wounded site, whereas $D c$-inoculated potato developed severe browning and soft rot symptoms (disease severity of $89.8 \%$ ). Co-treatment of MPP significantly reduced disease severity by $22.1 \%$. Taken together, major secondary metabolite MPP of ANU$301 \mathrm{CF}$ was identified to have antibacterial activity.

\section{Discussion}

Aspergillus, a well-known saprophytic filamentous fungal genus, play different biological roles in different niche, with Aspergillus niger and Aspergillus flavus being the most studied and significant species for their secondary metabolites (Hossain et al., 2017; Park et al., 2017; Yu et al., 2021). A. terreus, a less well-known and explored microbe, was recently discovered to be a significant biological control agent and plant growth promoting microorganism (Frisvad and Larsen, 2015; Vassileva et al., 2020). The biological control capabilities of $A$. terreus (ANU-301) against several plant diseases are addressed in this work.

The closely related phenolic compounds, such as MPP, 2,4-Di-tert-butylphenol (2,4-DTBP), and 2,6-bis(1,1dimethylethyl)-4-(1-methyl-1-phenylethyl)-phenol, are known to be toxic secondary metabolite produced by various group or organisms (Melappa et al., 2017; Shaaban et al., 2021; Zhao et al., 2020). 2,4-DTBP is a lipophilic phenol that has been identified as a lethal secondary metabolite in 169 species of organisms, including A. terreus (Aissaoui et al., 2019; Akshatha et al., 2016; Belghit et al., 2016; Lenartowicz et al., 2015; Varsha et al., 2015; Viszwapriya et al., 2016; Zhang et al., 2008; Zhao et al., 2020). 2,4DTBP is efficient against the agriculturally significant rootrot fungus $F$. oxysporum by suppressing spore germination and hyphal outgrowth through a possible interaction with $\beta$-tubulin in microtubules (Dharni et al., 2014). 2,4-DTBP also known to inhibit the production of quorum sensing (QS)-mediated biofilm formation, while it increases the hydration of the cell wall, resulting in decreased biofilm formation (Padmavathi et al., 2014). Intercellular communication in bacteria, technically referred to as QS, is a critical factor in disease spread and pathogenesis because it regulates biofilm formation. Reportedly, it plays an important role in development of Dickeya-induced Potato soft rot (Baltenneck et al., 2021). ANU-301 was also identified as a source of MPP and 2,6-bis(1-methyl-1-phenylethyl)phenol by GC-MS/MS analysis as the first and third most abundant chemical compounds, respectively. Unexpectedly, MPP did not show significant antifungal activity against FOL (Supplementary Fig. 1). In accordance with this result, CF of ANU-301 showed much lower antifungal activity against $F O L$ in CFA compared to its antifungal activity in DCA (Fig. 1). This may suggest that (1) antifungal activity of ANU-301 against FOL is not dependent on MPP production, and/or (2) ANU-301 can produce specific antifungal compounds against $F O L$ in the presence of the pathogen (Note that CF of ANU-301 prepared from the pathogen-free media show little antifungal activity against $F O L$, but still effective to restrict the growth of $F O L$ in DCA).

In GC-MS/MS analysis, we discovered 2,3,4,5-tetraphenyl-1H-pyrrole as the second highest peak from the analysis of CF of ANU-301. Pyrrole is a five-membered aromatic ring having the chemical formula $\mathrm{C}_{4} \mathrm{H}_{5} \mathrm{~N}$ (Ahmad et al., 2018). Pyrrole is a fundamental building block of biochemistry due to its flat electron-rich ring, which is particularly vulnerable to electrophilic assault and may react with a wide variety of biomolecules through hydrogen bonding and $\pi-\pi$ stacking interactions (Domagala et al., 2015). Analogs of pyrrole are being investigated as possible sources of antifungal and antibacterial activity (Bhardwaj et al., 2015). The antibacterial activity of this compound is controlled by substituting alternative molecules, scaffolds, or moiety, groups in the pyrrole ring following attached analogs, including the phenyl (diaryl) moiety (Wang et al., 2011; Arumugam et al., 2012; Bhosale et al., 2013; Jana et al., 2005; Raimondi et al., 2006; Thach et al., 2016; Varshney et al., 2017). 2,3,4,5-tetraphenyl-1H-pyrrole is a pyrrole derivative with four phenyl rings that has recently been shown to have antibacterial (mycobacterial) activity (Bhardwaj et al., 2015).

As fourth and fifth peak in GC-MS/MS analysis ANU301 shows octadecane and tetracosane respectively. Octadecane $\left(\mathrm{C}_{18} \mathrm{H}_{38}\right)$ and tetracosane $\left(\mathrm{C}_{24} \mathrm{H}_{50}\right)$ are aliphatic hydrocarbon (alkane) maintaining its general formula $\mathrm{C}_{\mathrm{n}} \mathrm{H}_{2 \mathrm{n}+2}$, is a dangerous environmental toxic chemicals in petroleumcontaminated soil consisting of recalcitrant compound make it non-degradable (Bajagain et al., 2018; Campo et al., 2017; Hamouda et al., 2016; Hussain et al., 2018; Meckenstock et al., 2016). Some recent reports proved that they also have significant antimicrobial properties (Abiona et al., 2019; Barupal et al., 2019; Bouhlal et al., 2020; Li et al., 2021; Rajaofera et al., 2019; Ramírez et al., 2021; Wang et al., 2020).

Tomato is a widely grown vegetable crop in the Solana- 
ceae family with high nutritional content and antioxidant effects (Nahar and Ullah et al., 2012). Fusarium wilt is strongly related with tomato production loss in field conditions (Chakraborty and Acharya, 2017). Blackleg and soft rot in potato, both caused by $D$. chrysanthemi, are among the most damaging bacterial diseases plaguing this world's fourth most important food crop (Pédron et al., 2021). The potentials of Aspergillus spp., particularly A. terreus, are currently underutilized (Galeano et al., 2021; Vassileva et al., 2020). Our investigation established its potential as a future contender for effective biological control agent.

\section{Conflicts of Interest}

No potential conflict of interest relevant to this article was reported.

\section{Acknowledgments}

This work was supported by a Research Grant of Andong National University.

\section{Electronic Supplementary Material}

Supplementary materials are available at The Plant Pathology Journal website (http://www.ppjonline.org/).

\section{References}

Ab Rahman, S. F. S., Singh, E., Pieterse, C. M. J. and Schenk, P. M. 2018. Emerging microbial biocontrol strategies for plant pathogens. Plant Sci. 267:102-111.

Abdallah, R. A. B., Jabnoun-Khiareddine, H., Mejdoub-Trabelsi, B. and Daami-Remadi, M. 2015. Soil-borne and compostborne Aspergillus species for biologically controlling postharvest diseases of potatoes incited by Fusarium sambucinum and Phytophthora erythroseptica. Plant Pathol. Microbiol. 6:10.

Abiona, D. L., Onawumi, O. O. E. and Oladoye, S. O. 2019. Analysis of oil fraction from Crinum jagus bulb and its antibacterial activity. In: 13th PARIS Int'l Conference on Agricultural, Chemical, Biological \& Environmental Sciences (PACBES-19), eds. by K. Maeda and L. Ma, pp. 64-67. PACBES-19, Paris, France.

Abri, Kuswinanti, T., Sengin, E. L. and Sjahrir, R. 2015. Production of indole acetic acid (IAA) hormone from fungal isolates collected from rhizosphere of aromatic rice in Tana Toraja. Int. J. Curr. Res. Biosci. Plant Biol. 2:198-201.

Ahmad, S., Alam, O., Naim, M. J., Shaquiquzzaman, M., Alam, M. M. and Iqbal, M. 2018. Pyrrole: an insight into recent pharmacological advances with structure activity relationship. Eur. J. Med. Chem. 157:527-561.
Aissaoui, N., Mahjoubi, M., Nas, F., Mghirbi, O., Arab, M., Souissi, Y., Hoceini, A., Masmoudi, A. S., Mosbah, A., Cherif, A. and Klouche-Khelil, N. 2019. Antibacterial potential of 2,4-di-tert-butylphenol and calixarene-based prodrugs from thermophilic Bacillus licheniformis isolated in Algerian hot spring. Geomicrobiol. J. 36:53-62.

Akshatha, J. V., Prakash, H. S. and Nalini, M. S. 2016. Actinomycete endophytes from the ethno medicinal plants of Southern India: antioxidant activity and characterization studies. $J$. Biol. Act. Prod. Nat. 6:166-172.

Al-Shibli, H., Dobretsov, S., Al-Nabhani, A., Maharachchikumbura, S. S. N., Rethinasamy, V. and Al-Sadi, A. M. 2019. Aspergillus terreus obtained from mangrove exhibits antagonistic activities against Pythium aphanidermatum-induced damping-off of cucumber. PeerJ 7:e7884.

Arumugam, N., Raghunathan, R., Almansour, A. I. and Karama, U. 2012. An efficient synthesis of highly functionalized novel chromeno[4,3- $b]$ pyrroles and indolizino[6,7-b]indoles as potent antimicrobial and antioxidant agents. Bioorg. Med. Chem. Lett. 22:1375-1379.

Bajagain, R., Park, Y. and Jeong, S.-W. 2018. Feasibility of oxidation-biodegradation serial foam spraying for total petroleum hydrocarbon removal without soil disturbance. Sci. Total Environ. 626:1236-1242.

Baltenneck, J., Reverchon, S. and Hommais, F. 2021. Quorum sensing regulation in phytopathogenic bacteria. Microorganisms 9:239.

Barupal, T., Meena, M. and Sharma, K. 2019. Inhibitory effects of leaf extract of Lawsonia inermis on Curvularia lunata and characterization of novel inhibitory compounds by GC-MS analysis. Biotechnol. Rep. 23:e00335.

Belghit, S., Driche, E. H., Bijani, C., Zitouni, A., Sabaou, N., Badji, B. and Mathieu, F. 2016. Activity of 2,4-Di-tertbutylphenol produced by a strain of Streptomyces mutabilis isolated from a Saharan soil against Candida albicans and other pathogenic fungi. J. Mycol. Med. 26:160-169.

Bhardwaj, V., Gumber, D., Abbot, V., Dhiman, S. and Sharma, P. 2015. Pyrrole: a resourceful small molecule in key medicinal hetero-aromatics. RSC Adv. 5:15233-15266.

Bhosale, J. D., Shirolkar, A. R., Pete, U. D., Zade, C. M., Mahajan, D. P., Hadole, C. D., Pawar, S. D., Patil, U. D., Dabur, R. and Bendre, R. S. 2013. Synthesis, characterization and biological activities of novel substituted formazans of 3,4-dimethyl-1H-pyrrole-2-carbohydrazide derivatives. J. Pharm. Res. 7:582-587.

Bodah, E. T. 2017. Root rot diseases in plants: a review of common causal agents and management strategies. Agric. Res. Technol. Open Access J. 5:555661.

Borisade, O. A., Uwaidem, Y. I. and Salami, A. E. 2017. Preliminary report on Fusarium oxysporum f. sp. lycopersici (Sensu lato) from some tomato producing agroecological areas in Southwestern Nigeria and susceptibility of F1-resistant tomato hybrid (F1-Lindo) to infection. Annu. Res. Rev. Biol. 18:19 . 
Bouhlal, F., Aqil, Y., Chamkhi, I., Belmaghraoui, W., Labjar, N., Hajjaji, S. E., Benabdellah, G. A., Aurag, J., Lotfi, E. M. and Mahi, M. E. 2020. GC-MS analysis, phenolic compounds quantification, antioxidant, and antibacterial activities of the hydro-alcoholic extract of spent coffee grounds. J. Biol. Act. Prod. Nat. 10:325-337.

Brookie, K. L., Best, G. I. and Conner, T. S. 2018. Intake of raw fruits and vegetables is associated with better mental health than intake of processed fruits and vegetables. Front. Psychol. 9:487.

Campo, R., Giustra, M. G., De Marchis, M., Freni, G. and Di Bella, G. 2017. Characterization and treatment proposals of shipboard slop wastewater contaminated by hydrocarbons. Water 9:581.

Cating, R. A., Hong, J. C., Palmateer, A. J., Stiles, C. M. and Dickstein, E. R. 2008. First report of bacterial soft rot on Vanda orchids caused by Dickeya chrysanthemi (Erwinia chrysanthemi) in the United States. Plant Dis. 92:977.

Cazar, M. E., Schmeda-Hirschmann, G. and Astudillo, L. 2005. Antimicrobial butyrolactone I derivatives from the Ecuadorian soil fungus Aspergillus terreus Thorn. var terreus. World J. Microbiol. Biotechnol. 21:1067-1075.

Chakraborty, N. and Acharya, K. 2017. "NO way"! says the plant to abiotic stress. Plant Gene 11:99-105.

Dharni, S., Sanchita, Maurya, A., Samad, A., Srivastava, S. K., Sharma, A. and Patra, D. D. 2014. Purification, characterization, and in vitro activity of 2,4-Di-tert-butylphenol from Pseudomonas monteilii PsF84: conformational and molecular docking studies. J. Agric. Food Chem. 62:6138-6146.

Domagala, A., Jarosz, T. and Lapkowski, M. 2015. Living on pyrrolic foundations: advances in natural and artificial bioactive pyrrole derivatives. Eur. J. Med. Chem. 100:176-187.

El-hawary, S. S., Moawad, A. S., Bahr, H. S., Abdelmohsen, U. R. and Mohammed, R. 2020. Natural product diversity from the endophytic fungi of the genus Aspergillus. RSC Adv. 10:22058-22079.

Frisvad, J. C. and Larsen, T. O. 2015. Chemodiversity in the genus Aspergillus. Appl. Microbiol. Biotechnol. 99:7859-7877.

Galeano, R. M. S., Franco, D. G., Chaves, P. O., Giannesi, G. C., Masui, D. C., Ruller, R., Corrêa, B. O., da Silva Brasil, M. and Zanoelo, F. F. 2021. Plant growth promoting potential of endophytic Aspergillus niger 9-p isolated from native forage grass in Pantanal of Nhecolândia region, Brazil. Rhizosphere 18:100332.

Ghosh, S. K., Banerjee, S. and Sengupta, C. 2017. Bioassay, characterization and estimation of siderophores from some important antagonistic fungi. J. Biopestic. 10:105-112.

Gordon, T. R. 2017. Fusarium oxysporum and the Fusarium wilt syndrome. Annu. Rev. Phytopathol. 55:23-39.

Hamouda, R. A. E. F., Sorour, N. M. and Yeheia, D. S. 2016. Biodegradation of crude oil by Anabaena oryzae, Chlorella kessleri and its consortium under mixotrophic conditions. Int. Biodeterior. Biodegrad. 112:128-134.

Hossain, M. M., Sultana, F. and Islam, S. 2017. Plant growth-pro- moting fungi (PGPF): phytostimulation and induced systemic resistance. In: Plant-microbe interactions in agro-ecological perspectives, eds. by D. Singh, H. Singh and R. Prabha, pp. 135-191. Springer, Singapore.

Hugouvieux-Cotte-Pattat, N., Condemine, G. and Shevchik, V. E. 2014. Bacterial pectate lyases, structural and functional diversity. Environ. Microbiol. Rep. 6:427-440.

Hussain, F., Hussain, I., Khan, A. H. A., Muhammad, Y. S., Iqbal, M., Soja, G., Reichenauer, T. G. and Yousaf, S. 2018. Combined application of biochar, compost, and bacterial consortia with Italian ryegrass enhanced phytoremediation of petroleum hydrocarbon contaminated soil. Environ. Exp. Bot. 153:80-88.

Jana, G. H., Jain, S., Arora, S. K. and Sinha, N. 2005. Synthesis of some diguanidino 1-methyl-2,5-diaryl-1 $H$-pyrroles as antifungal agents. Bioorg. Med. Chem. Lett. 15:3592-3595.

Javed, A., Shah, A. H., Hussain, A., Shinwari, Z. K., Khan, S. A., Khan, W. and Jan, S. A. 2020. Potential of endophytic fungus Aspergillus terreus as potent plant growth promoter. Pak. J. Bot. 52:1083-1086.

Joncy, A. M., Angappan, K., Nakkeeran, S., Tilak, M. and Umapathy, G. 2019. Exploration of antifungal metabolites of Aspergillus terreus (ENF12), an endophytic fungus isolated from mulberry (Morus Indica L.) leaf. Curr. J. Appl. Sci. Technol. 38:1-15.

Kumar, N. V., Rajam, K. S. and Rani, M. E. 2017. Plant growth promotion efficacy of indole acetic acid (IAA) produced by a mangrove associated fungi-Trichoderma viride VKF3. Int. J. Curr. Microbiol. Appl. Sci. 6:2692-2701.

Kumar, S., Stecher, G., Li, M., Knyaz, C. and Tamura, K. 2018. MEGA X: Molecular Evolutionary Genetics Analysis across computing platforms. Mol. Biol. Evol. 35:1547-1549.

Lenartowicz, P., Kafarski, P. and Lipok, J. 2015. The overproduction of 2,4-DTBP accompanying to the lack of available form of phosphorus during the biodegradative utilization of aminophosphonates by Aspergillus terreus. Biodegradation 26:6576.

Li, W., Long, Y., Mo, F., Shu, R., Yin, X., Wu, X., Zhang, R., Zhang, Z., He, L., Chen, T. and Chen, J. 2021. Antifungal activity and biocontrol mechanism of Fusicolla violacea J-1 against soft rot in kiwifruit caused by Alternaria alternata. J. Fungi 7:937.

Li, Z., Bai, T., Dai, L., Wang, F., Tao, J., Meng, S., Hu, Y., Wang, S. and $\mathrm{Hu}, \mathrm{S}$. 2016. A study of organic acid production in contrasts between two phosphate solubilizing fungi: Penicillium oxalicum and Aspergillus niger. Sci. Rep. 6:25313.

Liu, M., Sun, W., Wang, J., He, Y., Zhang, J., Li, F., Qi, C., Zhu, H., Xue, Y., Hu, Z. and Zhang, Y. 2018. Bioactive secondary metabolites from the marine-associated fungus Aspergillus terreus. Bioorg. Chem. 80:525-530.

Ma, B., Hibbing, M. E., Kim, H.-S., Reedy, R. M., Yedidia, I., Breuer, J., Breuer, J., Glasner, J. D., Perna, N. T., Kelman, A. and Charkowski, A. O. 2007. Host range and molecular phylogenies of the soft rot enterobacterial genera Pectobacterium 
and Dickeya. Phytopathology 97:1150-1163.

Mahmoud, A.-L. E. and Abd-Alla, M. H. 2001. Siderophore production by some microorganisms and their effect on Bradyrhizobium-mung bean symbiosis. Int. J. Agric. Biol. 3:157162.

Meckenstock, R. U., Boll, M., Mouttaki, H., Koelschbach, J. S., Cunha Tarouco, P., Weyrauch, P., Dong, X. and Himmelberg, A. M. 2016. Anaerobic degradation of benzene and polycyclic aromatic hydrocarbons. J. Mol. Microbiol. 26:92-118.

Melappa, G., Shilpashree, C. B., Channabasava and Prakash, B. 2017. In vitro antimitotic, antiproliferative and GC-MS studies on the methanolic extract of endophytic fungi, penicillium species of Tabebuia argentea bur \& k. Sch. Farmacia 65:301309.

Mosunova, O., Navarro-Muñoz, J. C. and Collemare, J. 2020. The biosynthesis of fungal secondary metabolites: from fundamentals to biotechnological applications. In: Reference module in life sciences, ed. by B. D. Roitberg, pp. 1-19. Elseiver Inc., London, UK.

Murali, M., Naziya, B., Ansari, M. A., Alomary, M. N., AlYahya, S., Almatroudi, A., Thriveni, M. C., Gowtham, H. G., Singh, S. B., Aiyaz, M., Kalegowda, N., Lakshmidevi, N. and Amruthesh, L. N. 2021. Bioprospecting of rhizosphere-resident fungi: their role and importance in sustainable agriculture. $J$. Fungi 7:314.

Nahar, K. and Ullah, S. M. 2012. Morphological and physiological characters of tomato (Lycopersicon esculentum Mill) cultivars under water stress. Bangladesh J. Agric. Res. 37:355360.

Nenwani, V., Doshi, P., Saha, T. and Rajkumar, S. 2010. Isolation and characterization of a fungal isolate for phosphate solubilization and plant growth promoting activity. J. Yeast Fungal Res. 1:009-014.

Ortega, H. E., Torres-Mendoza, D., Caballero E, Z. and CubillaRios, L. 2021. Structurally uncommon secondary metabolites derived from endophytic fungi. J. Fungi 7:570.

Ozimek, E., Jaroszuk-Ściseł, J., Bohacz, J., KorniłłowiczKowalska, T., Tyśkiewicz, R., Słomka, A., Nowak, A. and Hanaka, A., 2018. Synthesis of indoleacetic acid, gibberellic acid and ACC-deaminase by Mortierella strains promote winter wheat seedlings growth under different conditions. Int. J. Mol. Sci. 19:3218.

Padmavathi, A. R., Abinaya, B. and Pandian, S. K. 2014. Phenol, 2,4-bis(1,1-dimethylethyl) of marine bacterial origin inhibits quorum sensing mediated biofilm formation in the uropathogen Serratia marcescens. Biofouling 30:1111-1122.

Park, B. R., Son, H. J., Park, J. H., Kim, E. S., Heo, S. J., Youn, H. R., Koo, Y. M., Heo, A. Y., Choi, H. W., Sang, M. K., Lee, S.-W., Choi, S. H. and Hong, J. K. 2021. Chemical fungicides and Bacillus siamensis H30-3 against fungal and oomycete pathogens causing soil-borne strawberry diseases. Plant Pathol. J. 37:79-85.

Park, H.-S., Jun, S.-C., Han, K.-H., Hong, S.-B. and Yu, J.-H. 2017. Diversity, application, and synthetic biology of indus- trially important Aspergillus fungi. Adv. Appl. Microbiol. 100:161-202.

Patel, D., Patel, S., Thakar, P. and Saraf, M. 2017. Siderophore producing Aspergillus spp. as bioinoculant for enhanced growth of mung bean. Int. J. Adv. Agric. Sci. Technol. 6:111120.

Pédron, J., Schaerer, S., Kellenberger, I. and Van Gijsegem, F. 2021. Early emergence of Dickeya solani revealed by analysis of Dickeya diversity of potato blackleg and soft rot causing pathogens in Switzerland. Microorganisms 9:1187.

Pérombelon, M. C. M. 2002. Potato diseases caused by soft rot erwinias: an overview of pathogenesis. Plant Pathol. 51:1-12.

Potrykus, M., Golanowska, M., Sledz, W., Zoledowska, S., Motyka, A., Kolodziejska, A., Butrymowicz, J. and Lojkowska, E. 2016. Biodiversity of Dickeya spp. isolated from potato plants and water sources in temperate climate. Plant Dis. 100:408417.

Raimondi, M. V., Cascioferro, S., Schillaci, D. and Petruso, S. 2006. Synthesis and antimicrobial activity of new brominerich pyrrole derivatives related to monodeoxypyoluteorin. Eur. J. Med. Chem. 41:1439-1445.

Rajaofera, M. J. N., Wang, Y., Dahar, G. Y., Jin, P., Fan, L., Xu, L., Liu, W. and Miao, W. 2019. Volatile organic compounds of Bacillus atrophaeus HAB-5 inhibit the growth of Colletotrichum gloeosporioides. Pestic. Biochem. Physiol. 156:170176.

Ramírez, V., Martínez, J., Bustillos-Cristales, M. D. R., CatañedaAntonio, D., Munive, J.-A. and Baez, A. 2021. Bacillus cereus $\mathrm{MH} 778713$ elicits tomato plant protection against $\mathrm{Fu}$ sarium oxysporum. J. Appl. Microbiol. 132:470-482.

Salas-Marina, M. A., Silva-Flores, M. A., Cervantes-Badillo, M. G., Rosales-Saavedra, M. T., Islas-Osuna, M. A. and CasasFlores, S. 2011. The plant growth-promoting fungus Aspergillus ustus promotes growth and induces resistance against different lifestyle pathogens in Arabidopsis thaliana. J. Microbiol. Biotechnol. 21:686-696.

Samson, R., Legendre, J. B. and Christen, R., Fischer-Le Saux M., Achouak W. and Gardan L. 2005. Transfer of Pectobacterium chrysanthemi (Burkholder et al., 1953) Brenner et al. 1973 and Brenneria paradisiaca to the genus Dickeya gen. nov. as Dickeya chrysanthemi comb. nov. and Dickeya paradisiaca comb. nov. and delineation of four novel species, Dickeya dadantii sp. nov., Dickeya dianthicola sp. nov., Dickeya dieffenbachiae sp. nov. and Dickeya zeae sp. nov. Int. J. Syst. Evol. Microbiol. 55:1415-1427.

Šebesta, M., Urík, M., Bujdoš, M., Kolenčík, M., Vávra, I., Dobročka, E., Kim, H. and Matúš, P. 2020. Fungus Aspergillus niger processes exogenous zinc nanoparticles into a biogenic oxalate mineral. J. Fungi 6:210.

Shaaban, M., Ghani, M. A. and Issa, M. Y. 2021. New naturally occurring compounds from Sarcophyton trocheliophorum. Biointerface Res. Appl. Chem. 12:2285-2331.

Shin, D. J., Yoo, S.-J., Hong, J. K., Weon, H.-Y., Song, J. and Sang, M. K. 2019. Effect of Bacillus aryabhattai H26-2 and 
B. siamensis $\mathrm{H} 30-3$ on growth promotion and alleviation of heat and drought stresses in Chinese cabbage. Plant Pathol. J. 35:178-187.

Singh, V. K., Singh, H. B. and Upadhyay, R. S. 2017. Role of fusaric acid in the development of 'Fusarium wilt' symptoms in tomato: physiological, biochemical and proteomic perspectives. Plant Physiol. Biochem. 118:320-332.

Sławiak, M., van Beckhoven, J. R., Speksnijder, A. G. C. L., Czajkowski, R., Grabe, G. and van der Wolf, J. M. 2009. Biochemical and genetical analysis reveal a new clade of biovar 3 Dickeya spp. strains isolated from potato in Europe. Eur. J. Plant Pathol. 125:245-261.

Srinivas, C., Devi, D. N., Murthy, K. N., Mohan, C. D., Lakshmeesha, T. R., Singh, B., Kalagatur, N. K., Niranjana, S. R., Hashem, A., Alqarawi, A. A., Tabassum, B., Abd_Allah, E. F., Nayakaa, S. C. and Srivastava, R. K. 2019. Fusarium oxysporum $\mathrm{f}$. sp. lycopersici causal agent of vascular wilt disease of tomato: biology to diversity-a review. Saudi J. Biol. Sci. 26:1315-1324.

Thach, O., Mielczarek, M., Ma, C., Kutty, S. K., Yang, X., Black, D. S., Griffith, R., Lewis, P. J. and Kumar, N. 2016. From indole to pyrrole, furan, thiophene and pyridine: search for novel small molecule inhibitors of bacterial transcription initiation complex formation. Bioorg. Med. Chem. 24:11711182.

Toth, I. K., Van der Wolf, J. M., Saddler, G., Lojkowska, E., Hélias, V., Pirhonen, M., Tsror, L. and Elphinstone, J. G. 2011. Dickeya species: an emerging problem for potato production in Europe. Plant Pathol. 60:385-399.

Tsukagoshi, N., Kobayashi, T. and Kato, M. 2001. Regulation of the amylolytic and (hemi-) cellulolytic genes in aspergilli. $J$. Gen. Appl. Microbiol. 47:1-19.

van der Wolf, J. M., Nijhuis, E. H., Kowalewska, M. J., Saddler, G. S., Parkinson, N., Elphinstone, J. G., Pritchard, L., Toth, I. K., Lojkowska, E., Potrykus, M., Waleron, M., de Vos, P., Cleenwerck, I., Pirhonen, M., Garlant, L., Hélias, V., Pothier, J. F., Pflüger, V., Duffy, B., Tsror, L. and Manulis, S. 2014. Dickeya solani sp. nov., a pectinolytic plant-pathogenic bacterium isolated from potato (Solanum tuberosum). Int. J. Syst. Evol. Microbiol. 64:768-774.

Varsha, K. K., Devendra, L., Shilpa, G., Priya, S., Pandey, A. and Nampoothiri, K. M. 2015. 2,4-Di-tert-butyl phenol as the antifungal, antioxidant bioactive purified from a newly isolated Lactococcus sp. Int. J. Food Microbiol. 211:44-50.

Varshney, H., Ahmad, A., Rauf, A., Husain, F. M. and Ahmad, I. 2017. Synthesis and antimicrobial evaluation of fatty chain substituted 2,5-dimethyl pyrrole and 1,3-benzoxazin-4-one derivatives. J. Saudi Chem. Soc. 21(Suppl 1):S394-S402.

Vassileva, M., Malusá, E., Eichler-Löbermann, B. and Vassilev, N. 2020. Aspegillus terreus: from soil to industry and back. Microorganisms 8:1655.

Végh, A., Némethy, Z., Salamon, P., Mándoki, Z. and Palkovics, L. 2014. First report of bacterial wilt on chrysanthemum caused by Dickeya chrysanthemi (syn. Erwinia chrysanthemi) in Hungary. Plant Dis. 98:988.

Viszwapriya, D., Prithika, U., Deebika, S., Balamurugan, K. and Pandian, S. K. 2016. In vitro and in vivo antibiofilm potential of 2,4-Di-tert-butylphenol from seaweed surface associated bacterium Bacillus subtilis against group A streptococcus. Microbiol. Res. 191:19-31.

Wang, M.-Z., Xu, H., Liu, T.-W., Feng, Q., Yu, S.-J., Wang, S.-H. and Li, Z.-M. 2011. Design, synthesis and antifungal activities of novel pyrrole alkaloid analogs. Eur. J. Med. Chem. 46:1463-1472.

Wang, X., Li, C., Wang, M., Zhao, T. and Li, W. 2020. Bifunctional microcapsules with n-octadecane/thyme oil core and polyurea shell for high-efficiency thermal energy storage and antibiosis. Polymers 12:2226.

Waqas, M., Khan, A. L., Hamayun, M., Shahzad, R., Kang, S.M., Kim, J.-G. and Lee, I.-J. 2015. Endophytic fungi promote plant growth and mitigate the adverse effects of stem rot: an example of Penicillium citrinum and Aspergillus terreus. J. Plant Interact. 10:280-287.

White, T. J., Bruns, T., Lee, S. and Taylor, J. 1990. Amplification and direct sequencing of fungal ribosomal RNA genes for phylogenetics. In: PCR protocols: a guide to methods and applications, eds. by M. A. Innis, D. H. Gelfand, J. J. Sninsky and T. J. White, pp. 315-322. Academic Press, New York, USA.

Yu, R., Liu, J., Wang, Y., Wang, H. and Zhang, H. 2021. Aspergillus niger as a secondary metabolite factory. Front. Chem. 9:701022.

Zaman, K. A. U., Hu, Z., Wu, X., Hou, S., Saito, J., Kondratyuk, T. P., Pezzuto, J. M. and Cao, S. 2020. NF- $\kappa$ B inhibitory and antibacterial helvolic and fumagillin derivatives from Aspergillus terreus. J. Nat. Prod. 83:730-737.

Zhang, D., Gong, C. and Wei, H. 2008. Chemical constituents of the culture broth of Paenibacillus polymyxa HY96-2. J. East China Univ. Sci. Technol. 34:71.

Zhao, F., Wang, P., Lucardi, R. D., Su, Z. and Li, S. 2020. Natural sources and bioactivities of 2,4-di-tert-butylphenol and its analogs. Toxins 12:35. 